$\overline{\text { 研 究 }}$

電解による切削抵抗低減効果を利用した微細切削*

永田真生** 若林公宏** 山田真樹** 増沢隆久***

\title{
MICROCUTTING WITH REDUCED CUTTING FORCE BY ELECTROLYSIS
}

\author{
M. Nagata, K. Wakabayashi, M. Yamada and T. Masuzawa
}

\begin{abstract}
In this paper, we propose a microcutting method with a reduced machining force by applying an electrolytic passive film formation on the workpiece surface. This process realizes the machining of microstructure such as $10 \mu \mathrm{m}$ wide micro grooves which has been difficult to be machined by conventional cutting. A mirror surface which has the roughness $30 \mathrm{~nm}$ Ry is also obtained by this method.

Key Word. micro machining, machining force, electrolysis, passive film, mirror machining
\end{abstract}

\section{1. 緒論}

近年, 機器の高度化に伴い, 微細加工に対する 要求が高度化しつつある. 特にインクジェットプ リンタノズルやインク流路, マイクロレンズアレ イなどの微小光学素子では横方向および厚さと もに数ミクロンから数百ミクロン程度の立体形 状を高精度に加工する技術が求められている。

本来 2 次元的な加工法であるフォトリソグラフ イーにおいて，露光にシンクロトロン放射 X 線を 用いた LIGA プロセスは極めてアスペクト比の高 い形状の加工を可能とした ${ }^{1)}$ が，厚さ方向に形状 分布が無い 2.5 次元加工にとどまり，実現できる 形状に制限が生じる。これに対して，切削や放電 加工などは工具を位置決めして加工を行うこと により 3 次元加工を実現できる.

特に, マイクロ放電加エでは WEDG により直径 数ミクロン程度の工具を高精度に作製でき ${ }^{2)}$, 加 エ反力が小さいため, 微細な 3 次元加工を実現で

*電気加工学会全国大会 (1998)にて発表

**富士ゼロックス(株) 生産技術部

***東京大学生産技術研究所
きる3). しかし，加工に伴いわずかに電極が消耗 するため, 加工形状に精度の低下が生じる.

一方, WEDGによりオンマシンで微細な工具を創 成して切削加工を行う方法は工具のチャッキン グに伴う芯振れの問題を解決し, 切削加工が微細 加工へ適用可能であることを示した ${ }^{4)}$. しかし， 微小工具は直径の 2 乗に反比例して折れやすくな り，これを微細加工に適用するためには工具折損 に対する対策が不可欠となる.

一般には, 工具の心材に勒性材料を, 外周部に 硬質材料を用いて折れにくくするなど工具の強 度を向上させる工夫がなされるが, 数 $\mu \mathrm{m}$ レベル の微小工具に適用することは困難である.

そこで，工作物の被削性を向上させるため, 一 般に軟化あるいは脆化すると言われる金属の酸 化膜を電解により積極的に生じさせ，この部分の みを加工することにより，微細加工を行う方式を 提案する. 本報告で提案する加工方式は電解条件 としてはいわゆる不働態化領域 ${ }^{5)}$ を用いて金属内 部に酸化が進展することを防ぎながら連続的に 酸化膜の生成と切削を行うものである. 


\section{2. 加工原理}

図 1 に本加工方法の加工原理を示す.

工作物である金属表面（陽極）に対して，別途 設けた電極（陰極）との間に電解液を介して電解 電圧を印加する. 金属材料の種類に忘じて, 加工 面に不働態膜が生成する電解液の $\mathrm{pH}$ と電位を保 持することにより表面が不働態膜に覆われ，それ 以上の酸化や溶出が発生しなくなる. 図 2 に示す 鉄の電位 $\mathrm{pH}$ 図においては, 斜線部分が不働態化 領域となる.

電解液中での測定により, 純鉄で $2 \sim 7 \mathrm{~nm}$ (中性 硼酸塩溶液中） ${ }^{6)}$, SUS304 で 20〜 550nm，S45C で $320 \sim 1180 \mathrm{~nm}$ (中性硝酸ナトリウム溶液中） 7$) の$ 厚さを持つ不働態膜が形成されることが報告さ れている.

生成させた不働態膜は切削工具に対する抵抗 が小さく，極めて直径の小さい工具を使用しても， 折損が発生する可能性を低隇させることを可能 とする. 不働態膜を除去した直後は, 電解溶出を 防ぐ膜が失われた状態となり，再不働態化するま での間にわずかな電解溶出が起こって, さらに加 エを促進する.

また, 微細形状の加工を行う際には, 工具取り 付けの際の芯振れ誤差が加工精度に大きな影響 を与える. 本加工方法では, 切削工具の作製を WEDGによりオンマシンの状態で行うために, 工具 取り付けによる誤差は発生せず，機械の持つ回転 軸の振れのみが誤差要因となる。したがって，高 精度な微細形状加工を行うことが可能となる.

\section{3. 切削抵抗低減効果検証実験}

はじめに，金属表面を不働態化することにより 切削抵抗を低減する効果を確認する検証実験を 行った.

\section{1 実験装置および実験方法}

図 3 に実験に用いた装置を示す。

工作物（SUS304）に溝を形成し，その溝に電解

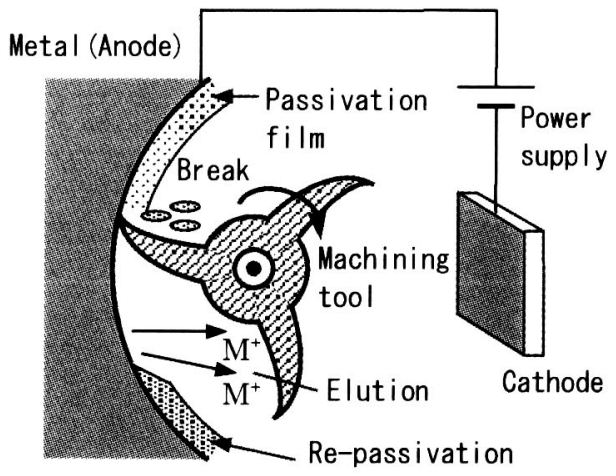

Fig. 1 Principle of machining

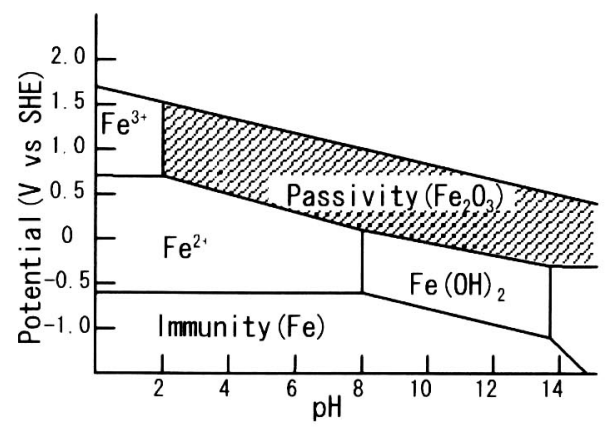

Fig. 2 Paurbaix diagram of Fe

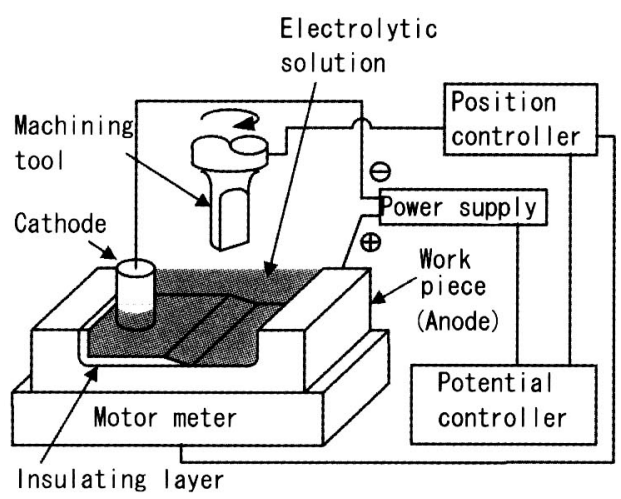

Fig. 3 Schematic diagram of experimental apparatus

液（1 規定硝酸ナトリウム水溶液）を満たす。電 解液中には電極 $(\mathrm{Cu})$ が工作物と絶縁層を介して 設置されている.

切削工具にかかる切削抵抗は, 工作物下の三分 
力動力計（日章電機製 LMC-3824）により常時測定 されており，切削抵抗の䦨值 $(0.02 \mathrm{~N})$ を超えた 場合には，切削工具位置制御装置へと信号が送ら え, 折損防止のため切削工具を退避させる動作を 行う。

切削工具は WEDG により作製した超硬合金のも のを用いた。

実験手順を図 4 に示す。

はじめに, 切削工具を電解液中から退避させた 状態で，工作物と電極間に電解電圧（1V）を 5 秒 間印加する。(図 $4(\mathrm{a})$ )

印加電圧を解除した後, 切削工具（超硬， $\phi 100$ $\mu \mathrm{m}, \mathrm{D}$ 形断面）を移動させ，工作物表面に形成さ れた不㗢態膜を切削加工する。（図 4(b))．

切削工具と工作物間の切削抵抗が $0.02 \mathrm{~N}$ を超え たら加工を中断し，切削工具を電解液中から退避 させる.（図 4(c) (d))

以上の電解電圧の印加から切削工具の退避まで を繰り返した場合と，電解電圧を印加せず、単に 所定の切削抵抗に至るまでの切削のみを繰り返 した場合との差を見ることで，金属表面を不働態 化することによる切削抵抗の低減効果を検証し た.

\section{2 実験結果}

電解電圧の印加の有無による切削加工量の差を 図 5 に示す。

切削、退避の操作を 15 回繰り返した状態で，電 解電圧を印加した場合には, 電解電圧を印加しな い場合と比較して，約 7 倍の累積加工量が得られ た.

電解電圧を印加しない場合には，ほとんど加工 量が得られていないのに対して, 電解電圧を印加 した場合には各サイクルごとに一定の加工量が 得られており, 累積加工量が比例的に増加してい る.

これは，工作物表面に不働態膜が形成されるこ

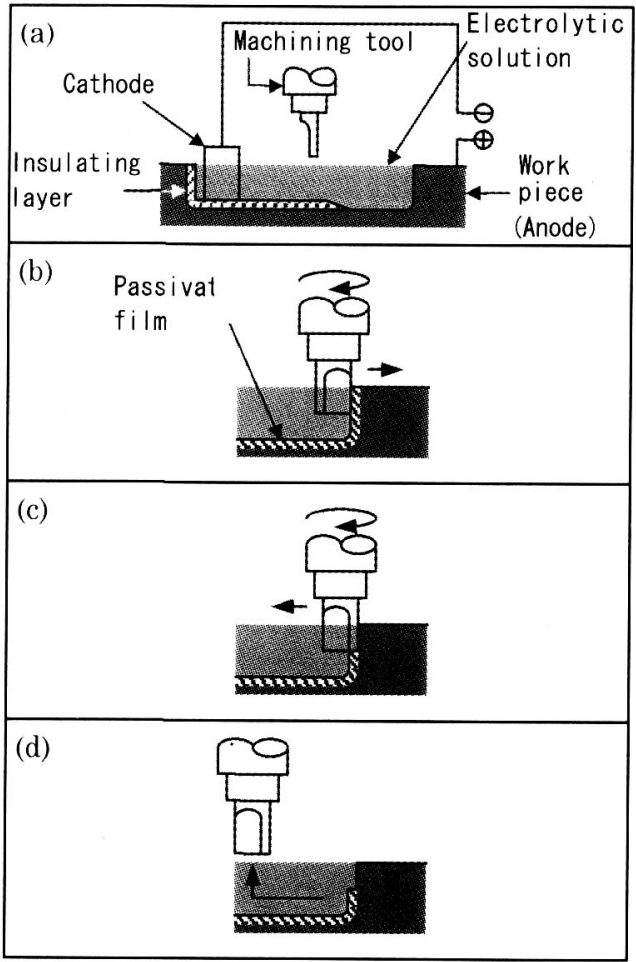

Fig. 4 Machining process

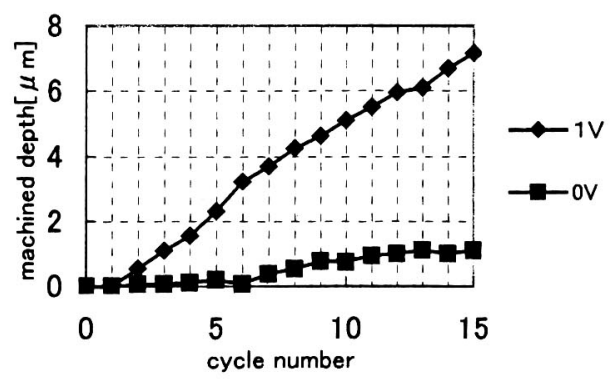

Fig. 5 Relationship between cycle number and machined depth

とにより切削抵抗が低減したために, 加工量が得 られたものと考えられる.このことから，金属表 面を不働態化することによる切削抵抗の低減効 果が検証された。

加工形状の摸式図を図 6 に示す，また，切削加 工後の表面状態の電子顕微鏡写真を図 7 , 図 8 に 示す．電解電圧の印加無しの場合が図 7 であり, 
電解電圧を印加した場合が図 8 である.

図 7 および図 8 から，加工面の表面状態に差は 見られないが，電解電圧を印加しない場合と印加 した場合とで，加工量に差が生じていることが分 かる.

加工後の表面状態も良好であり, 通常の切削加 工の約 7 倍の切削量が得られていることから, 微 細形状の切削加工への適用が期待できる.

\section{4. 微細形状加工実験}

加工面に不働態膜を形成することで，加工反力 低減効果が得られることが分かった．次に，この 効果を利用して, 微細形状加工, および表面粗さ を評価する実験を行った。

\section{1 実験装置および実験方法}

\subsection{1 加工条件抽出実験}

加工状態が良好で, 最大加工量が得られる加工 条件を抽出するために，実験計画法 ${ }^{8)}$ を用い，不 働態膜を生成するための重要な電解条件の中で,

電解電圧, 電解液濃度, 電圧印加時間, 電解ギャ ップの 4 つのパラメータに対して L9 直交実験を 行った.

ここでは，電解ギャップの影響を知るために， 切削工具を陰極として用い，その位置を制御する ことで電解ギャップを設定することとした.

実験手順を図 9 に示す.

陰極である切削工具を，工作物の加工面との間に 電解ギャップを介して電解液中に静止させた状 態で，電解電圧を印加した。（図 $9(\mathrm{a})$ )

電解電圧の印加を止め, 工作物の壁面に対して, 水平方向に切削加工を行った. 切り込み深さは 25 $\mu \mathrm{m}$, 工具回転数は $3000 \mathrm{rpm}$, 送り速度は $0.1 \mu$ m/sec とした. (図 9 (b))

切削加工を行っている間，工作物下に設置した 三分力動力計により切削抵抗を測定し，切削抵抗 が $0.01 \mathrm{~N}$ を超えた場合に切削工具を退避させた.

(図 9 (c) (d))

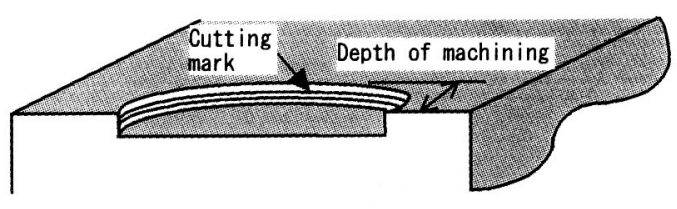

Fig. 6 Scheme of machined shape

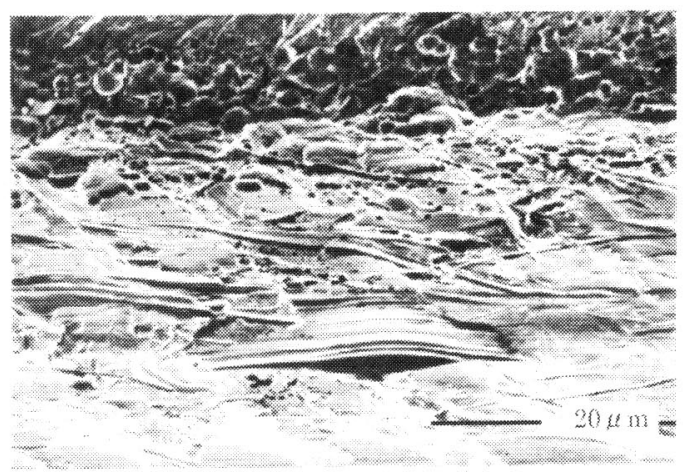

Fig. 7 Machined surface with no electrolysis

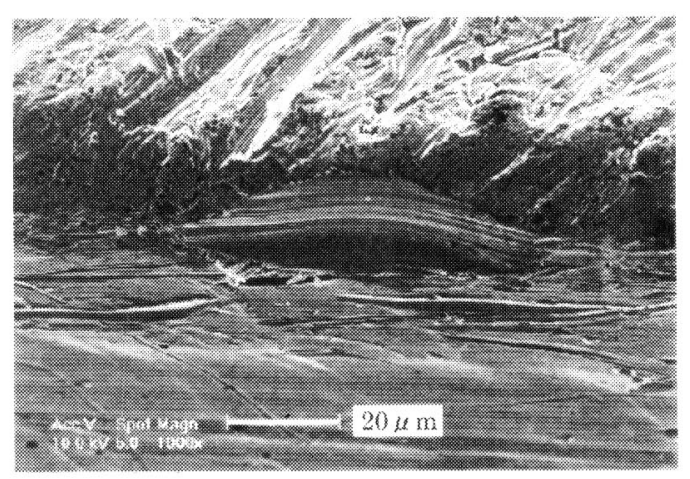

Fig. 8 Machined surface with electrolysis

切削工具により工作物が加工されている間の切 削抵抗の測定例を図 10 に示す.

不働態膜が十分に形成されていれば，不働態膜 を切削している間，切削抵抗の上昇は抑制される。 つまり，不働態膜を切削している状態より，金属 部分を切削している状態の方が，切削抵抗は大き くなると考えられる.

SUS304 では最大約 $500 \mathrm{~nm}$ の不働態膜の形成が予

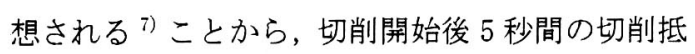
抗の上昇率（図 10 に示す曲線の微分值）を評価 の基準に用いた. 
また，各パラメータの各水準值は表 1 に示すも のを用いた。

\subsection{2 微細形状加工実験}

求められた加工条件での, 数 $\mu \mathrm{m}$ オーダの微細 工具による加工可能性の検証を行うために， $\phi 10$ $\mu \mathrm{m}$ の微細工具を用いた微細溝形状加工を行った. また，本加工法による加工形状精度を検証するた め三段形状加工を行った．加工装置は切削抵抗低 減効果検証実験で使用したもの（図 3）を用いた. ただし，電解ギャップは加工条件抽出実験の結 果から切削抵抗上昇率には影響の少ない要因で あることが示されたことと，切削工具とは別に電 極を設けた装置上の制約から，加工条件の電解ギ ヤップは $1 \mathrm{~mm}$ とした.

形状精度に関しては，加エした三段形状から， 工具の移動距離の設定值に対して, 加工後の形状 がどのようになっているのかを，階段部分の水平 方向と垂直方向について測定した。これにより， 本加工法における形状精度を求めた。

\section{1.3 表面粗さの測定}

微細領域への鏡面加工の可能性を検証するため に，切削抵抗低減効果検証実験で使用した加工装 置（図 3）と加工手順（図 4）により，加工面の 表面粗さを測定するサンプルを作製した。

作製したサンプル形状は，深さ $10 \mu \mathrm{m}$ ，幅 200 $\mu \mathrm{m}$ の浇形状である.

\section{2 実験結果}

\section{2.1 加工条件抽出実験}

図 11 (a)，および図 11(b)にL9直交実験により 得られた, 各パラメータの要因効果図を示す.

本実験にて用いた各パラメータの水準値の範囲 内においては，切削抵抗の上昇に対しては電解液 濃度と電解時間が大きな影響を持つことが分か った.

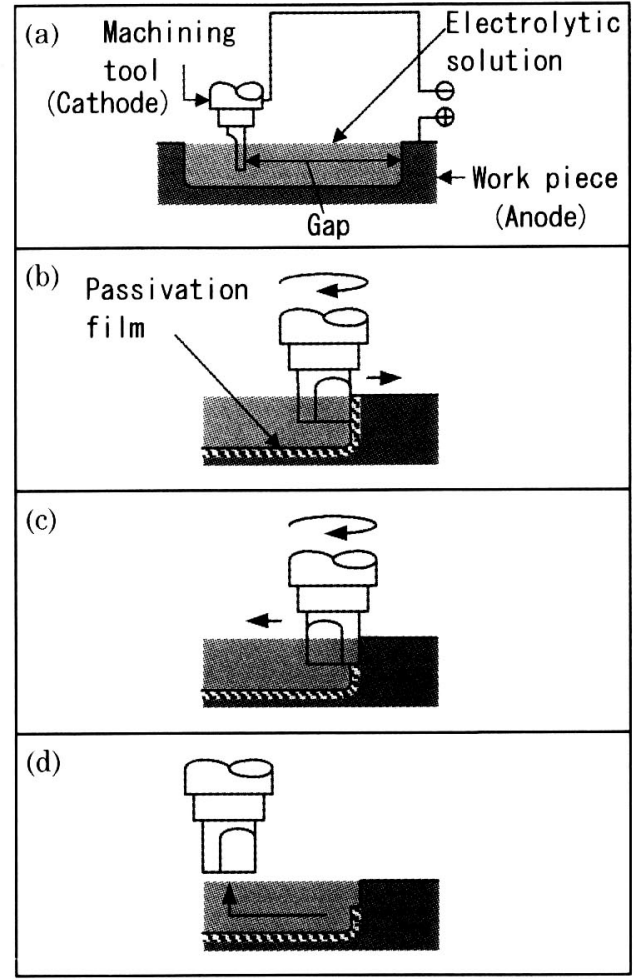

Fig. 9 Process of experiment

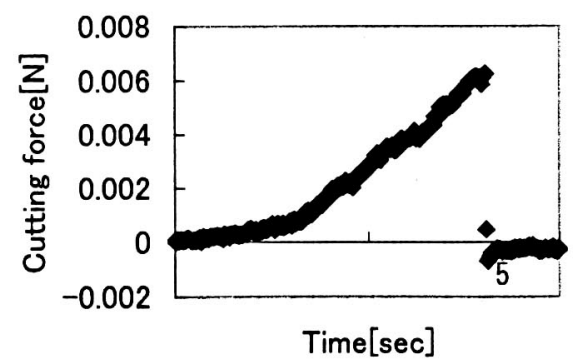

Fig. 10 Relationship between cutting force and time

Table 1 Parameters of experiment

\begin{tabular}{|l|l|}
\hline Parameter & Values \\
\hline Applied voltage & $1 \mathrm{~V}, 3 \mathrm{~V}, 5 \mathrm{~V}$ \\
\hline Concentration & $1 \mathrm{~N}, 0.1 \mathrm{~N}, 0.01 \mathrm{~N}$ \\
\hline Applied time & $5 \mathrm{sec}, 10 \mathrm{sec}, 20 \mathrm{sec}$ \\
\hline Gap & $1 \mu \mathrm{m}, 10 \mu \mathrm{m}, 100 \mu \mathrm{m}$ \\
\hline
\end{tabular}


各パラメータの要因効果図から求めた, 切削抵 抗低減効果を最も有する電解条件すなわち切削 抵抗上昇率が最小となる電解条件として，電解電 圧 $3 \mathrm{~V}$, 電解液濃度 $0.01 \mathrm{~N}$, 電解印加時間 $5 \mathrm{sec}$, 電 解ギャップ $1 \mu \mathrm{m}$ の条件で加工を行ったところ, 図 12 に示寸加工状態となった.

加工後の表面状態は粒界腐食により荒れた状態 となった。これは，電位を十側に高くしたために 生じる，いわゆる過不働態化状態となっているた めだと考えられる.

そこで，あらためて電解電圧を $2 \mathrm{~V}$ とし，その他 は同一条件で加工を行った.

このときの加工後の表面状態は図 13 に示すよ うに良好であることから，加工条件として，表 2 の条件を得た。

Table 2 Machining conditions

\begin{tabular}{|c|c|}
\hline Applied voltage & $2 \mathrm{~V}$ \\
\hline Concentration & $0.01 \mathrm{~N}$ \\
\hline Applied time & $5 \mathrm{sec}$ \\
\hline Gap & $1 \mu \mathrm{m}$ \\
\hline
\end{tabular}

\section{2. 2 微細形状加工実験}

加工後の微細溝形状を図 14 に、三段形状を図 15 に示す。

図 14 に示すように, 従来の切削加工では加工が 困難である $\phi 10 \mu \mathrm{m}$ 工具による加工を実現した.

切削加工は 3 次元の加工の自由度を持つために, レーザやフォトリソグラフィーといった, 従来の いわゆる 2.5 次元加工では困難である微細形状の 加工を実現する手段として，本方式の有用性を検 証することができた。

また，図 15 の三段形状から，形状精度として， 水平方向, 垂直方向ともに $0.3 \mu \mathrm{m}$ が得られた. この值は, 微細形状加工を行う上では十分なもの ではないが，今後，工具の形状や材質を工夫する ことで改善可能であると考えている.

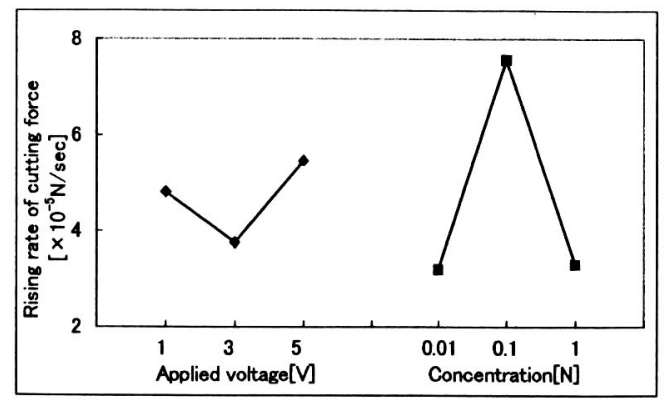

Fig. 11(a) Factorial effects diagram

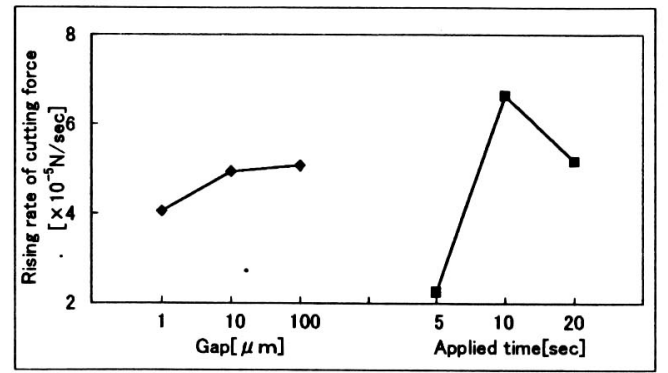

Fig. 11 (b) Factorial effects diagram

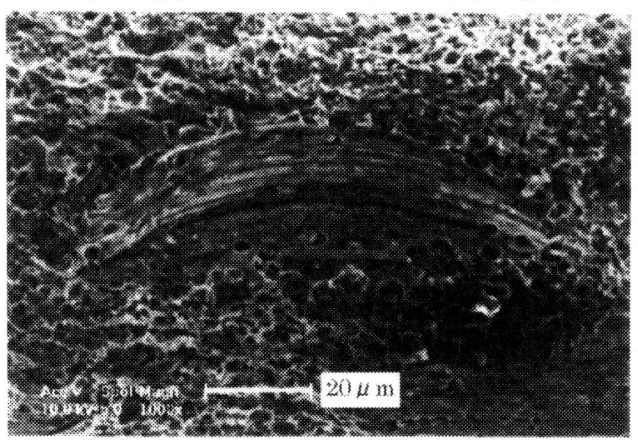

Fig. 12 Machined surface of selected condition by

L9-exper iment

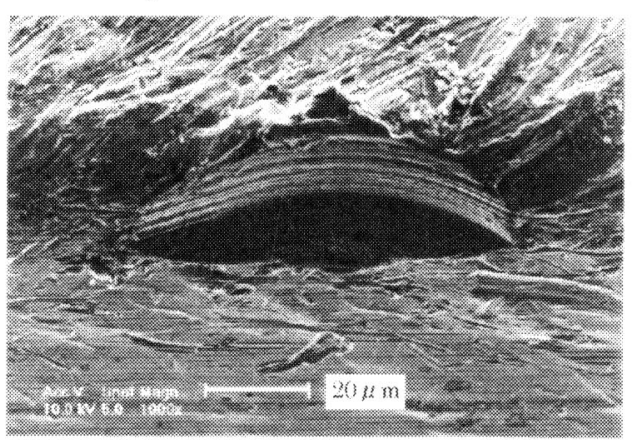

Fig. 13 Machined surface of $2 \mathrm{~V}$ applied voltage condition 


\section{2.3 表面粗さの測定}

作製した表面粗さ測定用のサンプルの加工状態 を図 16 に示す。

加工形状の電子顕微鏡写真加 工痕や電解による腐食がなく, 良好な加工面であ ることが分かる.

図 16 の斜線部の表面形状を白色干渉顕微鏡に て測定した結果を図 17 に示す.

得られた加工面の表面粗さは, $\mathrm{Ry}=29 \mathrm{~nm}$ となっ た.このことから，加工面は鏡面加工がなされて おり，研磨技術として十分に使用可能な技術であ ることが分かる.

また，図 18 に，図 16 の黒枠内加工面(左側) と, $\phi 200 \mu \mathrm{m}$ の超硬電極による SUS304 の放電加 工面（右側）との比較を示寸.

放電加工条件が $100 \mathrm{~V}, 1000 \mathrm{pF}$ ，表面粗さ Ry=1.6 $\mu \mathrm{m}$ の表面と比較して，良好な加工面が得られて いることが分かる.

このことから，放電加工後の表面に，鏡面仕上 げを行う技術として利用可能であることが示さ れた。

また，切削加工技術として用いることができる ために, 加工後に研磨工程を要しない微小領域の 鏡面切削加工技術として，さまざまな領域への展 開が期待できる.

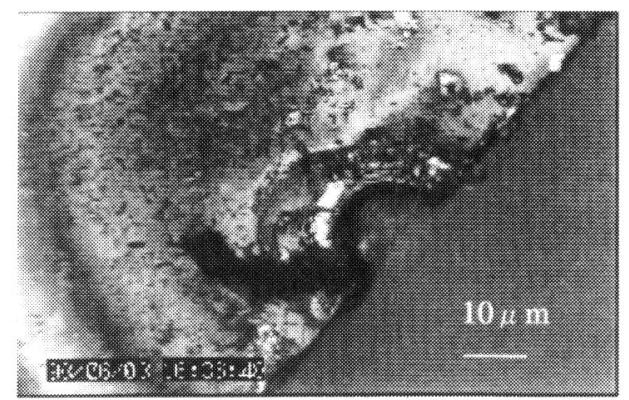

Fig. 14 Machined micro groove

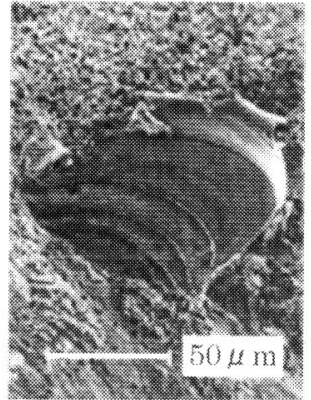

Photo with SEM

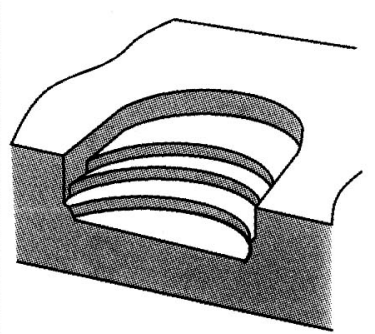

Scheme of machined shape
Fig. 15 Machined shape of 3-steps

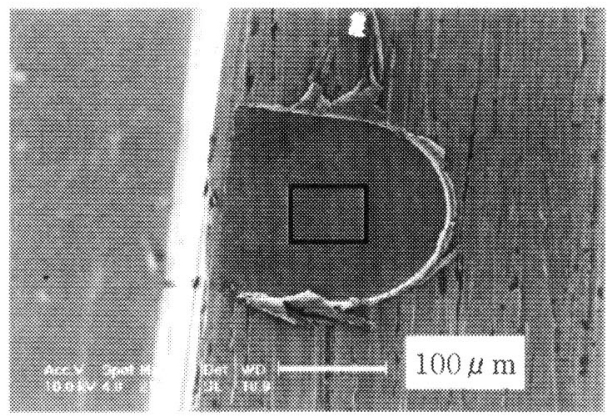

Fig. 16 Appearance of machined shape
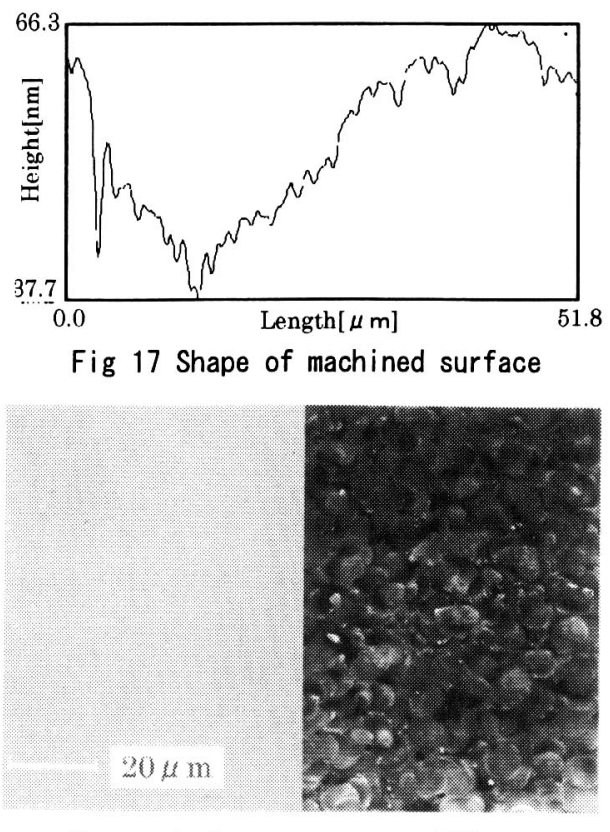

New method

EDM

(Working condition of EDM:100V, 1000pF)

Fig. 18 Comparison with EDMed surface 


\section{5. 結論}

工作物である金属表面に電解電圧を印加するこ とにより，金属表面に不働態膜を形成し工作物の 機械的性質を弱化させ，この不働態膜を除去加工 することにより低切削抵抗での加工を行う方法 を提案し，実験的検証を行った結果，以下の結論 を得た。

（1）電解電圧の印加により工作物表面に不働態 膜を形成することで, 切削抵抗を低減する効 果がある。

（2）切削抵抗低減効果には, 電解液濃度と電解 印加時間が大きな影響を与える.

（3）基礎実験から得たデータをもとに加工条件 設定を行った結果, 従来の切削加工では困難 であった $10 \mu \mathrm{m}$ 幅の溝加工を実現し，3 次元 微細形状加工への適用が可能であることを 示した.

（4）加工面の表面粗さとして, Ry=29nm の加工が 可能であり，微小領域の鏡面加工技術として 適用可能であることを示した。

\section{謝辞}

本研究に際し, 表面粗さ測定にご協力頂きまし た, 長岡技術科学大学 柳教授, 原助手, 東京工 業大学 塚田・笹島研究室の皆様に感謝いたしま す.

\section{参考文献}

1)E. W. Becker, W. Herfeld, P. Hagmann, A. Maner and

D. Munchmeyer: Fabrication of microstructures with high aspect ratios and great structural heights by synchrotron radiation lithography, galbanoforming, and plastic molding (LIGA process), Microelectronic Engineering 4 (1986) $35-56$

2)増沢隆久, 藤野正俊: 高精度微細軸加工の研究（第 1 報）一ワイヤ放電研削法の開発一，電気加工学 会誌, Vo124, No48, 14-28

3)增沢隆久, 河田耕一, 佐藤健夫 : 微小穴の放電加 エについて，電気加工技術，Vol. 4, No.7(1981) 18-23

4)佐藤達志，增沢隆久，藤野正俊，大西幸夫 : WEDG のマイクロドリル・エンドミルへの応用, 1989 年 度精密工学会春季大会学術講演会講演論文集 1091-1092

5)M. Pourbaix:"Atlas of Electrochemical Equilibria in aqueous solutions", Pergamon Press

6) 佐藤教男：金属の不働態化と表面不働態皮膜, DENKI KAGAKU, Vol46, No.11 (1978), p585

7)杉江他曽宏ら：電解加工における電極表面の酸化 物皮膜の役割, 金属表面技術, Vol. 32, No. 8, 1981, p403

8)田口玄一 : 開発・設計段階の品質工学、(財) 日本 規格協会 